See Article page 106 in the December 2020 issue.

\section{Commentary: Trifecta valve: Does a word of caution prevail?}

\author{
Ko Bando, MD, $\mathrm{PhD}$
}

The use of bioprosthetic valves for surgical aortic valve replacement has increased during the last few decades due to continuous improvements in durability and hemodynamic performance. ${ }^{1,2}$ Many commercially available aortic bioprosthetic valves have been modified to increase their effective orifice area, minimize transvalvular pressure gradient, and avoid patient-prosthetic mismatch (PPM) after surgery. ${ }^{3}$

The Trifecta bioprosthetic aortic valve (Abbott, St Paul, Minn) is a trileaflet, stented pericardial valve designed for supra-annular placement during surgical aortic valve replacement. The valve leaflets are made from a single bovine pericardial tissue that is externally mounted on a titanium stent to maximize hemodynamic performance. . $^{3,4}$ The Trifecta valve has shown excellent hemodynamic performance with a low transvalvular gradient, acceptable effective orifice area, and low rates of PPM. ${ }^{5}$ However, a number of early Trifecta valve failures have been reported, and the most common cause of dysfunction was aortic regurgitation due to leaflet tear involving the noncoronary cusp and pannus formation in the inflow portion. ${ }^{6-10}$ Although the mechanism of these early failures is unclear, it has been suggested that technical failures, such as incautious knot tying, oversized valve selection, and accidental bending of the sewing ring or the titanium stent posts, may cause a change in valve geometry, eventually leading to leaflet damage and tearing. ${ }^{11}$ To avoid these technical pitfalls, the next-generation Trifecta valve with Glide Technology (Trifecta GT; Abbott) was introduced in 2016. This new valve allows easier suturing and better placement

\footnotetext{
From the Department of Cardiac Surgery, The Jikei University School of Medicine, Tokyo, Japan.

Disclosures: The author reported no conflicts of interest.

The Journal policy requires editors and reviewers to disclose conflicts of interest and to decline handling or reviewing manuscripts for which they may have a conflict of interest. The editors and reviewers of this article have no conflicts of interest.

Received for publication Nov 5, 2020; revisions received Nov 5, 2020; accepted for publication Nov 13, 2020; available ahead of print Nov 18, 2020.

Address for reprints: Ko Bando, MD, PhD, Department of Cardiac Surgery, The Jikei University School of Medicine, 3-25-8, Nishi-Shimbashi, Minato-ku, Tokyo, 1058461, Japan (E-mail: kobando@yacht.ocn.ne.jp or kobando@jikei.ac.jp).

JTCVS Techniques 2021;5:21-2

2666-2507

Copyright (C) 2020 The Authors. Published by Elsevier Inc. on behalf of The American Association for Thoracic Surgery. This is an open access article under the CC BY-NCND license (http://creativecommons.org/licenses/by-nc-nd/4.0/).

https://doi.org/10.1016/j.xjtc.2020.11.010
}

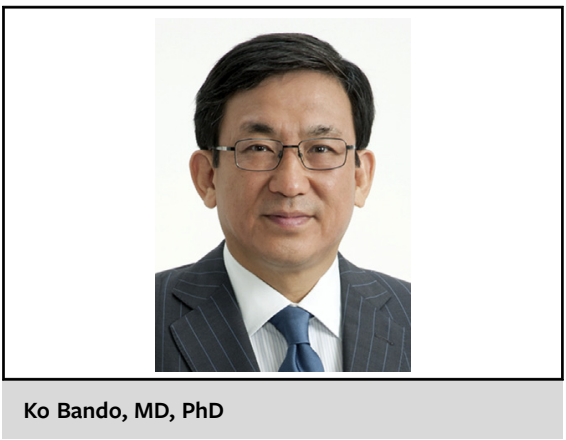

CENTRAL MESSAGE

Although Trifecta valves provided excellent hemodynamics, unpredictable structural valve deterioration associated with abrupt leaflet tear remains a major concern.

in the native annulus, with a modified holder to facilitate parachuting and seating to minimize distortion to the stent and leaflets. ${ }^{12}$

Thocuta and colleagues ${ }^{13}$ reported an unexpected early failure of the refined Trifecta GT that presented as newly diagnosed severe aortic insufficiency associated with a detached cusp at the stent post between the noncoronary and the right coronary cusps. ${ }^{13}$

Noncalcified leaflet tears at the stent post or at the bottom of the leaflet without significant leaflet calcification are rather typical for Trifecta valves, whereas slow progress of calcification has been the primary cause of structural valve deterioration (SVD) in other types of bioprosthetic valves. ${ }^{12}$ Given the characteristics and timing of the SVD in the newer Trifecta GT, hemodynamic or mechanical stress on the externally mounted leaflet of the valve may contribute to the incidence of SVD, as has been seen among other externally mounted leaflet valves, including the Ionescu-Shiley valves in the $1980 \mathrm{~s},{ }^{14,15}$ and the recentgeneration Mitroflow valves in the 2000s. ${ }^{16}$

Trifecta valves provided excellent early- to mid-term hemodynamic performance and a very low rate of PPM up to 6 or 7 years after surgery. ${ }^{3,12,17}$ The absolute number of observed SVD cases remains limited. ${ }^{12,17}$ However, clinical presentation of SVD caused by abrupt valve tears often involves sudden-onset severe dyspnea and heart failure and may require emergent redo surgery or a valve-in-valve procedure. $^{12,13,18}$ 
Physicians involved in the follow-up of these patients should always keep in mind the possibility of rapid SVD in the Trifecta valve. Thus, I recommend a "word of caution" regarding this valve.

\section{References}

1. Goldstone AB, Chiu P, Baiocchi M, Lingala B, Patrick WL, Fischbein MP, et al Mechanical or biologic prostheses for aortic-valve and mitral-valve replacement. N Engl J Med. 2017;377:1847-57.

2. Brown JM, O'CarBrien SM, Wu C, Sikora JA, Griffith BP, Gammie JS. Isolated aortic valve replacement in North America comprising 108,687 patients in 10 years: change in risks, valve types, and outcomes in the Society of Thoracic Surgeons national database. J Thorac Cardiovasc Surg. 2009;137:82-90.

3. Bavaria JE, Desai ND, Cheung A, Petracek MR, Groh MA, Borger MA, et al. The St Jude Medical Trifecta aortic pericardial valve: results from a global, multicenter, prospective clinical trial. J Thorac Cardiovasc Surg. 2014;147:590-7.

4. Kilic A, Sultan I, Navid F, Aranda-Michel A, Chu D, Thoma F, et al. Trifecta aortic bioprosthesis: midterm results in 1,953 patients form a single center. Ann Thorac Surg. 2019;107:1356-63.

5. Phan K, Ha H, Phan S, Misfeld M, Di Eusanio M, Yan TD. Early hemodynamic performance of the third generation St Jude Trifecta aortic prosthesis: a systematic review and meta-analysis. J Thorac Cardiovasc Surg. 2015;149:1567-75.

6. Sexena P, Greason KL, Schaff HV. Early structural valve deterioration of the Trifecta aortic valve biologic prosthesis: a word of caution. J Thorac Cardiovasc Surg. 2014;147:e10-1.

7. Campisi S, Camilleri L, Innorta A, Azarnoush K. Early failures of Trifecta aortic bioprosthesis. J Thorac Cardiovasc Surg. 2014;148:e133-4.
8. Haussig S, Schuler G, Linke A. Treatment of a failing St Jude Medical Trifecta aortic bioprosthesis. J Thorac Cardiovasc Surg. 2014;148:e133-4.

9. Kaira A, Rehman H, Ramchandani M, Barker CM, Lawrie GM, Reul RM, et al Early Trifecta valve failure: report of a cluster of cases from a tertiary care referral center. J Thorac Cardiovasc Surg. 2017;154:1235-40.

10. Eichinger S, Badreldin AMA, Eichinger WB. Early degeneration caused by cusp tear of first-generation Trifecta bioprosthesis. Ann Thorac Surg. 2018;106:e297-8.

11. Jamieson WRE. St Jude Medical Trifecta aortic prosthesis: considerations for implantation. J Thorac Cardiovasc Surg. 2015;149:1576-7.

12. Anselmi A, Ruggieri VG, Lelong B, Flecher E, Corbineau H, Langanay T, et al. Mid-term durability of the Trifecta bioprosthesis for aortic valve replacement. $J$ Thorac Cardiovasc Surg. 2017; 153:21-8.

13. Thocuta L, Liesman D, Kim K, Fukuhara S. Early failure of the Trifecta GT bioprostheses. J Thorac Cardiovasc Surg Tech. 2020;4:106-8.

14. Walley VM, Keon CA, Khalili M, Moher D, Campagna MC, Keon WJ. IonescuShiley valve failure I: experience with 125 standard-profile explants. Ann Thorac Surg. 1992;54:111-6.

15. Walley VM, Keon CA, Khalili M, Moher D, Campagna MC, Keon WJ. IonescuShiley valve failure II: experience with 25 low-profile explants. Ann Thorac Surg. 1992;54:117-23.

16. Sénage T, Le Tourneau T, Foucher Y, Pattier S, Cueff C, Michel M, et al. Early structural valve deterioration of Mitroflow aortic bioprosthesis: mode, incidence and impact on outcome in a large cohort of patients. Circulation. 2014;130:2012-20.

17. Lehmann S, Jawad K, Dieterlen MT, Hoyer A, Garbade J, Davierwala P, et al. Durability and clinical experience using a bovine pericardial prosthetic aortic valve. J Thorac Cardiovasc Surg. November 27, 2019 [Epub ahead of print].

18. Biancari F, Valtola A, Juvonen T, Husso A, Dahlbacka S, Laakso T, et al. Trifecta versus Perimount Magna Ease aortic valve prostheses. Ann Thorac Surg. 2020; 110:879-88. 